\title{
Papers
}

\section{College Crowd-in: How Private Donations Positively Affect Alumni Giving}

Received (in revised form): March 22, 2008

\section{Michael A. Gottfried}

is a doctoral student in the Applied Economics Group at the Wharton School at the University of Pennsylvania. He is also an Institute of Education Sciences (IES) Pre-Doctoral Fellow. In addition to research on donations in higher education, Michael also studies the effects of school management on academic outcomes.

\begin{abstract}
The issue of donor behavior and crowding out has been pertinent in the economics literature, both theoretically and empirically. Aggregate research has not been decisive, nor have many studies analyzed education institutions. I begin with a theoretical model of crowding-out versus crowding-in donor behavior. I then employ a fixed effects econometric model to three samples-total universities, public universities, and private universities. By implementing a longer time period and larger sample than previously seen in the literature, I can examine the crowd-out versus crowd-in effect of nonalumni private donations on
\end{abstract}

\footnotetext{
Author's Contact Address:

Michael A. Gottfried

Applied Economics Group

The Wharton School

University of Pennsylvania

1400 Steinberg Hall-Dietrich Hall

3620 Locust Walk

Philadelphia, PA 19104

USA

Email: mgottfr2@wharton.upenn.edu
}

alumni donations in the 12 -year period from 1995 to 2006. The results demonstrate a statistically significant crowding-in effect-the charitable behavior of parents, corporations, and foundations positively influences alumni donating behavior. The reason may be that these nonalumni private donations serve as a signal of increasing school quality.

International Journal of Educational Advancement (2008) 8, 51-70. doi:10.1057/ijea.2008.8

\section{Keywords:}

economic impact, educational economics, educational finance

\section{Introduction}

The issue of donor behavior and crowding out has been pertinent in the economics literature, both theoretically and empirically. The aggregate research has not been decisive, nor have many studies analyzed institutions of higher 
education. Thus, in this paper, I assess the theoretical foundations from previous research on the effect of crowding-out and subsequently apply them to this uncharted sub-sector of empirical research by implementing a longer time period and larger sample than previously seen in the literature.

In particular, I examine the crowdout versus crowd-in effect of nonalumni private donations on alumni donations in the 12 -year period from 1995 to 2006. The results demonstrate a statistically significant crowd-in effect-the charitable behavior of parents, corporations, and foundations positively influences alumni donating behavior. To derive these results, I begin with a theoretical model of crowding-out versus crowd-in behavior. Based on this theoretical foundation, I employ a fixed-effects econometric model to three samples. First, I employ my model for 1,422 US colleges and universities. Drawn from the original sample, I then evaluate two smaller sub-samples: all US public universities and all US private universities. The empirical outcome suggests that there is a crowd-in effect that is significantly different from zero within the realm of giving in higher education. The reason may be that private donations from parents, corporations, or foundations may serve as a signal of increasing quality within a school. As such, when a private donor provides funds to a particular university, the alumni of that institution react positively.

The debate on crowd-out versus crowd-in is not clear-cut. Even in the narrow scope of the relationship between charitable donations and governmental contributions, there is an extremely wide spectrum of conclusions. For instance, there is evidence for dollar-for-dollar crowdout (Roberts, 1984), partial crowd-out (Abrams and Schmitz, 1978; Steinberg, 1985; Andreoni and Payne, 2001), and no crowd-out whatsoever (Reece, 1979). On the other hand, both Sugden (1982) and Rose-Ackerman (1981) suggest analyses that yield crowding-in effects, whereby an increase in government expenditures result in an increase in private donations. Moreover, there are gray areas in this research, where both crowd-out and crowd-in effects are presented simultaneously within the same paper. Schiff (1985) indicates that some types of government spending do crowd-out a significant amount of private donations. He also finds that increases in other types of government spending, however, appear to promote a crowdin effect.

The interpretations underlying this wide array of results are also diverse. For instance, authors have attributed crowding out to warm glow (Andreoni, 1990, 1993), level of control and other private benefits associated with donation levels (Andreoni, 1993; Andreoni and Payne, 2001), and social pressure (RoseAckerman, 1986; Rabin, 1997). Those who support the crowd-in hypothesis assert that one group's donations may signal institutional quality and increase the reputation of the organization (Hodsoll, 1984; Mulcahy, 1992; Wyszomirski and Mulcahy, 1995; Connolly, 1997; Vesterlund, 2003).

The majority of the empirical studies focus on the relationship between governmental grants and private organizations in the context of nonprofits, such as social services (Steinberg, 1985; Andreoni and Payne, 
2001) and public radio stations (Kingma, 1989). A few studies, however, do examine the effect of crowding out in the arena of higher education. In one study, McPherson and Schapiro (1991) support a positive relationship between federal aid and university aid to undergraduates at four-year colleges. On the other hand, Ehrenberg et al. (1993) find that federal funding actually crowds-out university support of graduate education. As with most studies on nonprofits, in both of these studies the independent variable is governmental contributions.

Only one study in the field highlights the relationship between one set of private donations and anotherand is hence in-line with the scope of this paper. The author, Connolly (1997), explores the relationship between internal and external funding of academic research and finds a crowd-in effect, as a result of signaling higher academic quality. That is, an academic institution can expect to receive higher donations from one source when the other source provides a higher level of contribution.

Although this study confirms the crowd-in effect found by McPherson and Shapiro (1991), it does highlight the conflicting evidence-even within the smaller sub-field of higher education-on positive versus negative effects of one group's contribution on another.

This paper will provide clarity on both axes-on crowd-out versus crowd-in effects and then on the resulting interpretation. Like Connolly (1997), the essence of this paper examines private donations within the higher education sector. Unlike prior research, which all too often focuses on the relationship between governmental and private contributions, this paper continues to examine the effect that one subset of private donations has on another, both in terms of dollar value and number of donors. In particular, I ask the question, what is the effect of a change in parent, corporate, or foundation contributions on alumni contributions? Using a panel data set with more institutions than previously implemented in the literature, and employing this data for a longer time period than yet examined in the field, in this paper I find evidence of a crowd-in effect. The results support the idea that one source of funding positively stimulates another source, hence providing support for the hypothesis that donations signal institutional quality.

The remainder of the paper is as follows. The second section describes the economic theory underlying the alumni's donative behavior with respect to crowding-in and crowdingout. The third section presents the econometric model employed on the panel dataset, and the fourth section presents the data and results. The last section concludes.

\section{Theory}

This section of the paper develops a theoretical model under which we can study the effect of nonalumni contributions on alumni donations. Before diving into the economic model at hand, it is important to raise three principal assumptions, first derived by Sugden (1982). First is the publicness assumption, which provides for the fact that the charitable activity is in itself a public good from which donors derive utility. Whether the gain in utility makes our economic agent 
financially well-off (i.e., greater goods or services provided to him or her) or whether the agent receives what the literature refers to as a "warm glow" is irrelevant for this analysis. All that matters here is that economics agents receive some sort of utility increase from charitable donations to their alma maters. The second assumption is that our alumni are utility maximizers, as consistent with standard economic behavior. The final assumption is that each alumnus takes everyone else's contributions as given, when deciding how much to donate.

The model utilized in this paper begins with a framework in which nonalumni (parent, corporation, and religious organization) move first (hence reducing endogeneity) and then alumni donations subsequently occur. Individuals will choose their contribution levels to maximize their utility. In maximizing their utility, however, the alumni agents never directly consume the good to which they contribute.

There are two players in the model: alumni donor $i$ and nonalumni private donor $i$, both of which contribute a certain dollar level to university $i$. Alumni are exogenously endowed with a certain level of wealth, $w_{i}$. They have the decision power to allocate their spending between consumption of a private good $x_{i}$ and gift giving to the public good (i.e., the university) with amount $g_{i}$. Let $n$ be the total number of individuals and institutions that provide funding to the university good, and let $G=\sum_{i=1}^{n} g_{i}$ be the total amount of university donations. The utility function of each alumnus can thus be written as

$$
U_{i}=U_{i}\left(x_{i}, G, g_{i}\right)
$$

where $i=1 \ldots n$.
Let us write the donations of everyone except our alumni donor as follows $G_{-i}=\Sigma_{-i \neq i} g_{j}$. As such, the alumni's optimal donation can be determined by solving:

$$
\begin{array}{rc}
\max _{x_{i}, G, g_{i}} & U_{i}\left(x_{i}, G, g_{i}\right) \\
\text { subject to } & x_{i}+g_{i}=w_{i}, \\
\text { and } & G_{-i}+g_{i}=G
\end{array}
$$

Let us assume that $G_{-i}$ is treated exogenously. Hence, by substituting $g_{i}=G-G_{-i}$ into the above maximization function and in turn substituting the budget constraint into the utility function, the alumni's maximization problem becomes:

$$
\max _{G} U_{i}\left(w_{i}+G_{-i}-G, G, G-G_{-i}\right)
$$

Differentiating this with respect to $G$ and subsequently solving yields the following results:

$$
G=f_{i}\left(w_{i}+G_{-i}, G_{-i}\right)
$$

If we recall from above that our original maximization constraints contained the equation $G_{-i}+g_{i}=G$, we can derive the optimal donation by our alumni as follows:

$$
g_{i}^{\star}=f_{i}\left(w_{i}+G_{-i}, G_{-i}\right)-G_{-i}
$$

The optimal donation provided by our alumni now depends only on two arguments-the alumni's initial wealth endowment and the donations of other institutions, which, recall in this evaluation, are private institutions. We can see from this optimal donation equation how a nonalumni donation directly influences an alumni's donative behavior. In particular, if $f_{i}\left(w_{i}+G_{-i}\right.$, $\left.G_{-i}\right)<G_{-i}$, then the resulting donation 
by the alumnus will be negative. Hence, crowding out occurs. On the other hand, if $f_{i}\left(w_{i}+G_{-i}, G_{-i}\right)>G_{-i}$, we have a crowd-in effect.

Recall that the focus here is on changes to donations levels. To examine the possibility of both crowdout and crowd-in donor response to nonalumni donative behavior, I must look at the rate of change in the alumni's gift giving behavior to the university based on nonalumni contributions. To do so, I rely on the formulation of the Mackay and Whitney (1980) derivation of the income and substation effects of an individual's demand for charity. Transforming their model into one that appropriately fits the alumni utility profile, we can derive the following equation:

$$
\frac{\partial g_{i}}{\partial G_{-1}}=\frac{\partial g_{i}^{u}}{\partial G_{-1}}+\frac{\partial g_{i}}{\partial w_{i}}\left[\frac{\partial g_{i}^{u}}{\partial G_{-1}}-\frac{\partial x^{u}}{\partial G_{-1}}\right]
$$

The left-hand side of this equation asks how a change in nonalumni donations affects alumni giving, which is of key importance to this paper. The right-hand side breaks the change in alumni giving into both substitution and income effects. The first time on the right-hand side is the substitution effect. It states that holding utility constant, the change in an alumni's donation spending is due to a change in nonalumni contributions.

The income effect is in the brackets of the equation. The first term is the same as the substitution effect. The second term explains how the alumni donor's spending on private goods changes with respect to changes in nonalumni contributions. Overall, the brackets define the difference between how the alumni can spend his marginal dollar-either as a public good or as a private good. If the bracketed term is positive, then the alumnus is undersatisified with the level of nonalumni contributions to the university. As a result, the alumnus will spend more money on contributions to his university. If the bracketed term is negative, then the alumnus is oversatisified with the nonalumni component of contributions and hence spends more of his income on private goods. Finally, the alumnus can be classified as satisfied if the terms in brackets are equivalent.

From this equation, we can make the conclusion that crowd-out will exist unambiguously only if $g_{i}$ and $G_{-1}$ are perfect substitutes and if the alumni is oversatisfied or satisfied. In this case, the substitution effects are negative and therefore the entire righthand side also becomes negative. In any other case, the right-hand side may be positive or negative, hence leaving room for both crowd-out or crowd-in effects.

\section{Empirical Specification}

To begin this section, it is important to note that donative behavior of alumni can be decomposed into two parts: the dollar donation size and the number of donors. This paper will evaluate both aspects. Let us define $D_{i t}$ as the total dollar value of donations to university $i$ in year $t$, and $N_{i t}$ as the number of alumni donating. With these two components, the empirical question asked here is whether changes of both levels of nonalumni donations and nonalumni donors affect alumni dollars and alumni donor numbers. Given the two components of total 
donations, I define the following two econometric models:

$$
D_{i t}=\alpha_{0}+\alpha_{1} G_{i, t-1}+\alpha_{2} X_{i t}+\alpha_{3} T_{t}+\varepsilon_{i t}
$$

and

$$
N_{i t}=\beta_{0}+\beta_{1} G_{i, t-1}+\beta_{2} X_{i t}+\beta_{3} T_{t}+\varepsilon_{i t}
$$

To fit the two equations above, I have constructed a panel set on the 12 years of institutional data, from 1995 to 2006. Specifically, $D_{i t}$ and $N_{i t}$ are the dependent variables over time for a particular school. Of key importance is $G_{-i, t-1}$, which is a one-year lagged matrix of donative behavior by parents, corporations, and foundations. This variable is in dollars. Because of the possibility of endogeneity between $G_{i}$ and $D_{i}$ or $G_{i}$ and $N_{i}$, I make the assumption of an information lag in nonalumni private support. That is, lagging values of $G_{i}$ by one year implies that alumni donors must first acquire information on the nonalumni private donors before determining their level or dollar amount of giving. This method of reducing endogeneity in giving has been supported in the economics literature on government support and crowd-out (Khanna et al., 1995; Brooks, 2003). Note that the crowd-out/crowd-in parameters are $\alpha_{1}$ and $\beta_{1}$, the coefficients on nonalumni private donations.

Other independent variables in the econometric equations above are $X_{i t}$ which includes university characteristic variables such as school endowment, school enrollment, and school solicitation efforts, and $T_{t}$, which are year fixed effects that account for macro level time varying shocks and also serve as a proxy for income. Note that having variables such as solicitation efforts and year dummies will account for macro-economic events that would boost alumni income and will also enable the model to control for capital campaigns, which would be conducted through solicitation efforts. Additionally, the error term accounts for differences across schools and follows standard econometric assumptions.

\section{Data}

The data on donation values and other university attributions are sourced from the Voluntary Support of Education Survey program, developed by the "Council for Aid to Education" (CAE). The Council for Aid to Education is a national nonprofit organization and is the sole source of empirical data on private giving to education. An affiliate of the RAND Corporation from 1996 to 2005, CAE became an independent nonprofit in October of 2005.

It is important to be clear about the definitions of both alumni and nonalumni private donations. First, alumni donors are those defined as former students who have earned some credit toward one of the degrees, certificates, or diplomas offered by the school. Second are the nonalumni private donors, which include parents, corporations, and foundations. All of these sources are nongovernment donations, retaining consistency with the goal to study the effects of private donations on other private donations within higher education.

Specifically, parents are defined as being family of current and former students at the institution. Note that parents who are alumni are categorized as alumni, not as parents. Second, corporations include gift donors from 
not only for-profit corporate entities but also from partnerships, cooperatives, company-sponsored foundations (i.e., a gift from Ford Motor Company would be corporate, whereas a gift from Ford Foundation would not be), and industry trade associations. Finally, foundations include personal and family foundations and other foundations and trusts that are private tax-exempt entities operated exclusively for charitable purposes. It does not include company-sponsored foundations, which fall under the category of corporations.

Importantly, not all grant-making organizations that use the word "foundation" in their titles are included in this category. For example, the National Science Foundation and the Empire State Foundation are not private tax-exempt entities and therefore their grants are not included in a report of private voluntary support. This is important because grants from the National Science Foundation are clear-cut signals of school quality, as they provide grants to promising research proposals. On the other hand, a gift from the Ford Foundation may not provide a direct link to school quality. Alumni may, however, still behave as if it does.

Table 1 provides summary statistics for the nondummy variables. Of key interest in this paper are two dependent variables for the two estimation equations: alumni dollars donated and number of donors. Figure 1 provides a graph of the respective total dollar and total number values for these variables over the 12-year period. Dollar value is on the left-hand $y$-axis, and total number of alumni
Table 1: Total sample summary statistics, 1995-2006

\begin{tabular}{|c|c|c|c|}
\hline (In millions) & Mean & $\begin{array}{l}\text { Standard } \\
\text { deviation }\end{array}$ & Maximum \\
\hline Alumni dollars ${ }^{\mathrm{a}}$ & 5.88 & 17.39 & 258.22 \\
\hline $\begin{array}{l}\text { Number of alumni } \\
\text { donors }\end{array}$ & 0.04 & 0.06 & 0.46 \\
\hline Parent dollars ${ }^{\mathrm{a}}$ & 0.37 & 1.23 & 23.28 \\
\hline Corporate dollars ${ }^{\mathrm{a}}$ & 3.58 & 9.69 & 107.09 \\
\hline Foundation dollars ${ }^{\mathrm{a}}$ & 4.77 & 14.79 & 203.37 \\
\hline Endowment $\mathrm{t}^{\mathrm{a}}$ & 247.18 & 990.19 & $19,319.07$ \\
\hline Enrollment count & 0.01 & 0.01 & 0.11 \\
\hline $\begin{array}{l}\text { Number of alumni } \\
\text { solicited }\end{array}$ & 0.03 & 0.05 & 0.38 \\
\hline
\end{tabular}

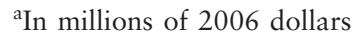

donors is on the right axis, both in millions. As we can see from Figure 1, there has been a clear trend in the increase in both number of alumni and in dollar value donated to the major sample of universities, although total dollars donated has been more volatile. This pattern is consistent with Brooks (2003), who finds that for nonprofit organizations, dollar value fluctuates more greatly than do the number of donors. For the 12-year period studied, the compound annual growth rate (CAGR) of these two figures is approximately 4 percent for total number of alumni donating and 8 percent for total dollars provided.

Figures 2 and 3 examine the relationship between alumni and nonalumni donative behavior and dollars given. In Figure 2, both dollars donated by alumni and dollars donated by nonalumni exhibit an upward trend, although there is more volatility in the alumni trend. The CAGRs for both alumni and nonalumni dollars are approximately 8 percent. Figure 3 shows total number 


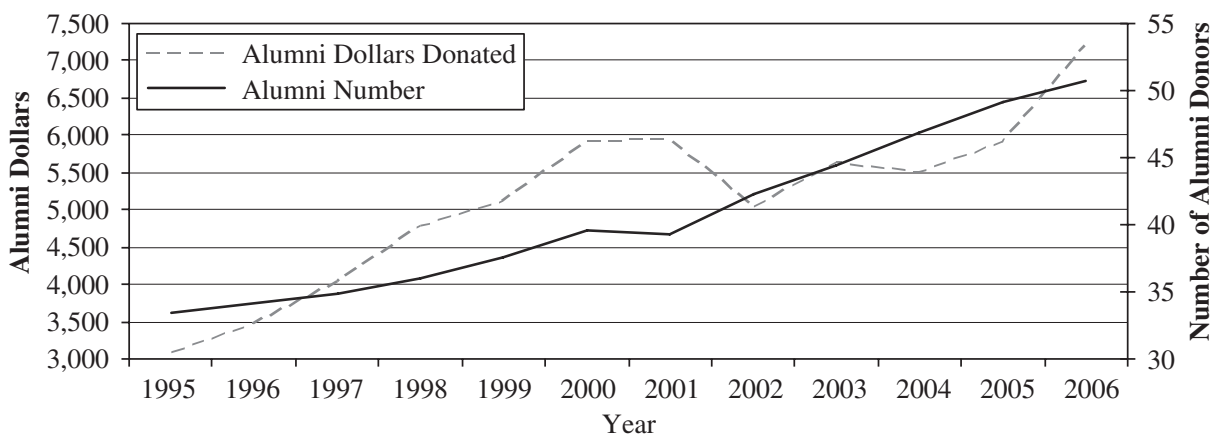

Figure 1: Total sample-Alumni number and dollars (in millions)

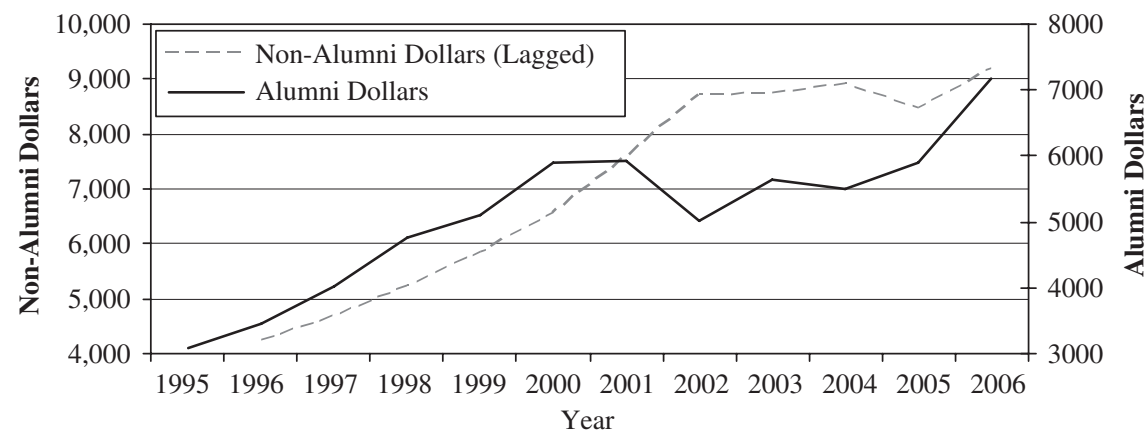

Figure 2: Alumni dollars versus nonalumni dollars (in millions)

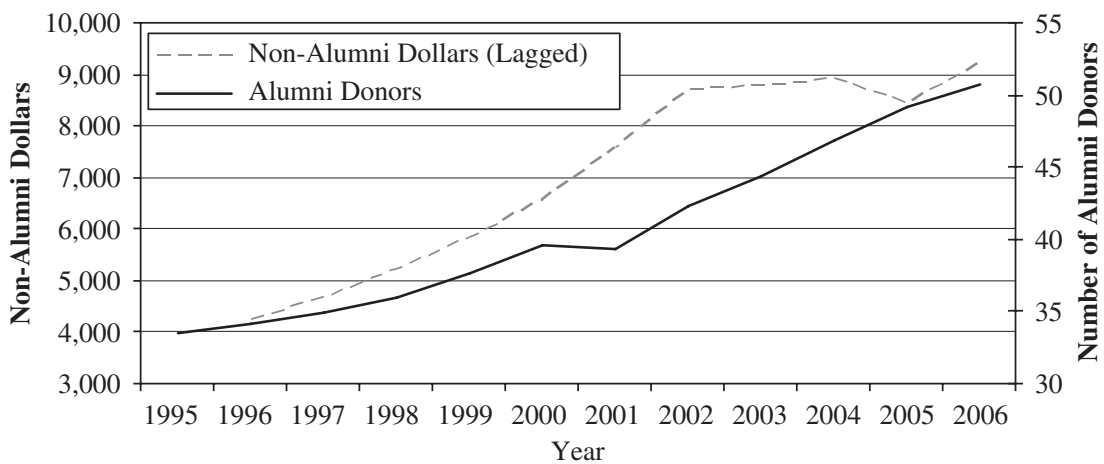

Figure 3: Alumni number versus nonalumni dollars (in millions)

of donors, with both lines again displaying an upward trend. The volatility of number of alumni donors is, however, much smaller than the value of alumni dollars as seen in Figure 2.
Results

Based on the economic theory and econometric specification laid out above, this section will provide clarity on the debate of the effect of the 
donations of one group on the donation spending of another group. Building on previous empirical literature on crowding out (particularly in arena of nonprofit organizations), this paper utilizes the longest time period and the largest data set yet seen. I have constructed a panel data set from 1995 to 2006 that combines school-specific information in order to provide a unique perspective within the literature of alumni generosity. The advantage of this large data set is that it encompasses levels of donations through periods of major economic upturns and downturns in a sample of 1,422 schools. In the next section, I analyze my findings with a sub-sample of 525 public institutions and 897 private universities. With this new dataset, I am not only able to discuss the previous literature on crowding out, but also to assess the previous literature on alumni giving.

Table 2 provides the regression analyses for total dollars and Table 3 that for total alumni. Each regression provides detail on a two-way fixed effects regression model. The dependent variable-alumni dollars donated or number of alumni-as well as nonalumni private donation variables, alumni solicitation, endowment, and enrollment are in natural logarithm form.

Beginning with the full sample of schools (which I will break into smaller sub-groups in the following section), I employ the aforementioned econometric model to assess a panel data set of 1,422 schools from 1995 to 2006. From this data set, the Hausman Test (Hausman, 1978) rejects the implementation of the random-effects model at a $p$-value of 0.000 in favor of a fixed effects model. Intuitively, a fixed-effects model is appropriate because this statistical technique can control for specific university characteristics that lack variation. Additionally, I control for year effects by including year dummies for the period 1995 to 2006 .

In all regressions, the key parameters are the crowd-out/crowd-in effect coefficients $-\alpha_{1}$ and $\beta_{1}$ as specified in the econometrics section-which are the coefficients on nonalumni private donations (parent, corporation, foundation, or total). With a crowdout effect, we expect to see negative coefficients, whereas those associated with a crowd-in effect will be positive. Observe that the full model with alumni dollars donated is displayed in regressions (1) through (8). In these first eight models, every single coefficient on parent, corporation, and foundation is positive at either the 1 or 5 percent statistical level. Examining Table 2 more closely, the coefficients range from 3 to 3.1 percent for parent donations, 3.1 to 3.7 percent for corporations, and 1.2 to 2.9 percent for foundations. The interpretation of these coefficients is as follows. Looking at the full model, equation (1), the crowd-in effect implies that that a one percent increase in parent, corporate, or foundation dollars in year $(t-1)$ predicts a respective $3,3.2$, and 2.7 percent increase in alumni donations in year $t$.

Note that the largest crowd-in coefficient arises in model (8), where the key independent variable is "total nonalumni," or the sum of parent, corporate, and foundation dollar donations. Here, a 1 percent increase in the cumulative private nonalumni donations in year $(t-1)$ will spur 


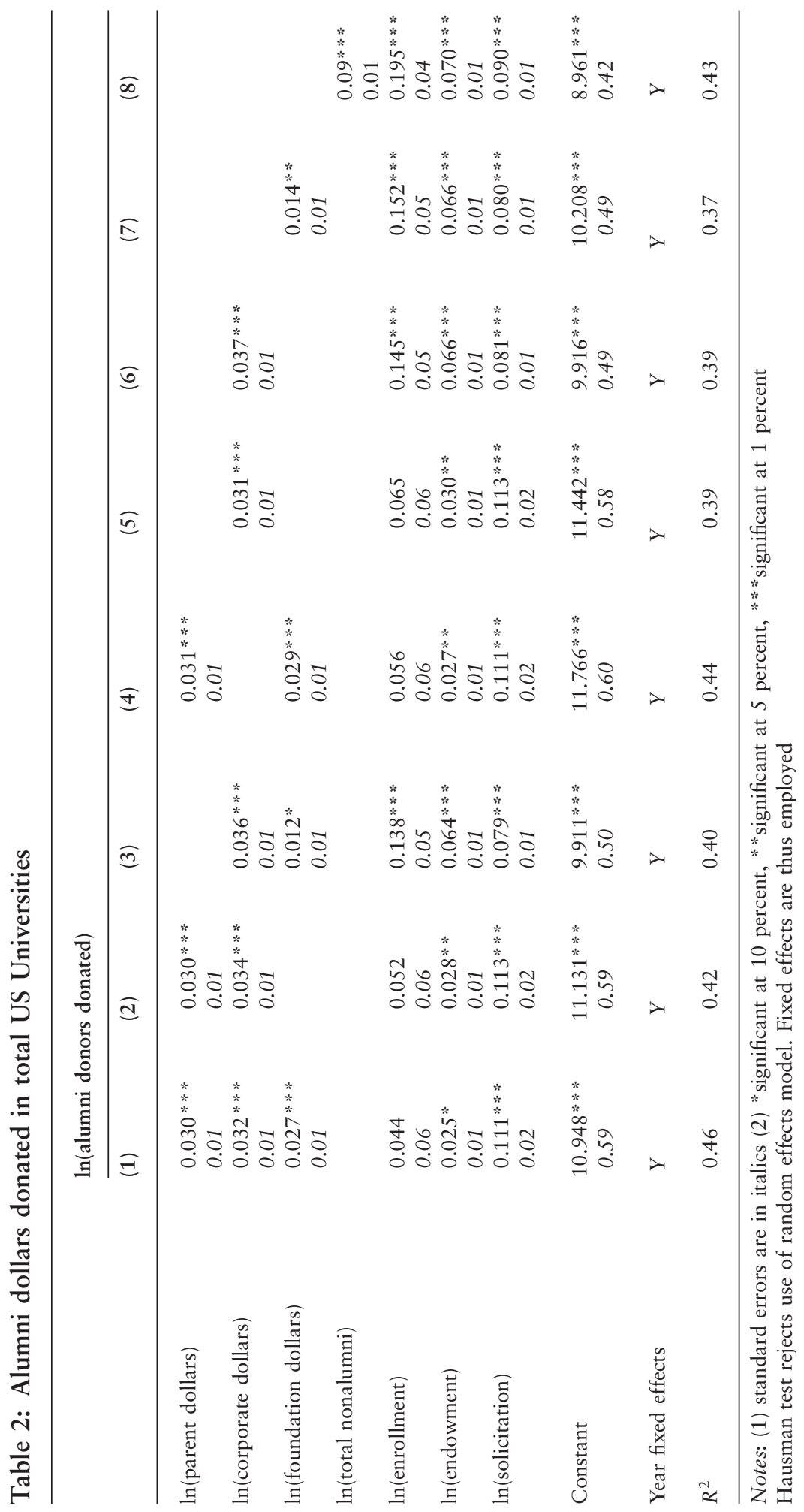


a 9 percent increase in alumni dollars donated in year $t$.

Examining Table 3 provides a similar crowd-in interpretation to that provided in Table 2. The coefficients on parent and corporations are significant and positive, respectively at the 1 and 5 percent levels. Foundation dollar donations, albeit not statistically significant, are still positive. For parent and corporate dollars, a 1 percent increase in either of these two sources will spur a statistically significant and positive increase in the number of alumni who donate. Note that much like in Table 2, the final regression in Table 3 holds the largest crowd-in effect (at the 1 percent statistical level of significance), with total dollars having a 4 percent increase effect on number of alumni donors.

Overall, within all 16 regressions examined thus far, the results support the crowd-in effects hypothesis. For every dollar given by a nonalumni private donor, there is actually an increase in alumni support. Like Connolly (1997) suggests, a crowd-in donative effect may indicate that information about one group's donation provides a positive signal on institutional quality. Rather than being repelled by a university's increase in private funding, an alumnus may interpret a parent, corporate, or foundation donation as a positive attribute of the institution and hence may choose to support it further.

Aside from the main variables of interest, other effects are apparent in these regression equations. Therefore, I briefly assess the control variables. Endowment is either positive and statistically significant or is negative and not statistically significant. In either case, the coefficients hover extremely close to 0 . Hence, these results may partially refute Oster's work (2001), in which she finds that endowment has a negative crowdingout effect in the most recent years of her data. I suspect that Oster's result is limited by the fact that her sample size is significantly smaller and that her time period does not include the major macroeconomic events that my work incorporates. Second, enrollment unsurprisingly demonstrates that an increase in student body will yield an increase in the total dollars donated and total student contributors. Finally, a university's alumni solicitation efforts are statistically significant and positive regarding alumni donation and turnout. This result on solicitation confirms the work of Gottfried and Johnson (2006).

\section{Extending the Model: Public versus Private Universities}

I evaluate the above econometric specification on two sub-samples from the previous panel data set to determine if a crowd-in effect remains apparent in a more homogenous group of universities. As such, I employ two panel data sets, consisting of 525 public and 897 private universities, in the 12-year period from 1995 to 2006, and conduct a similar analysis.

To begin this second set of empirical assessments, the Hausman Test (Hausman, 1978) rejects the random effects model in favor of a fixed effects model at a $p$-value of 0.000 . Similar to the above analyses of all schools, Tables 4 to 7 provide detail on the two-way fixed-effects regression analyses. Although the samples have been modified, both the dependent and independent variables have remained 


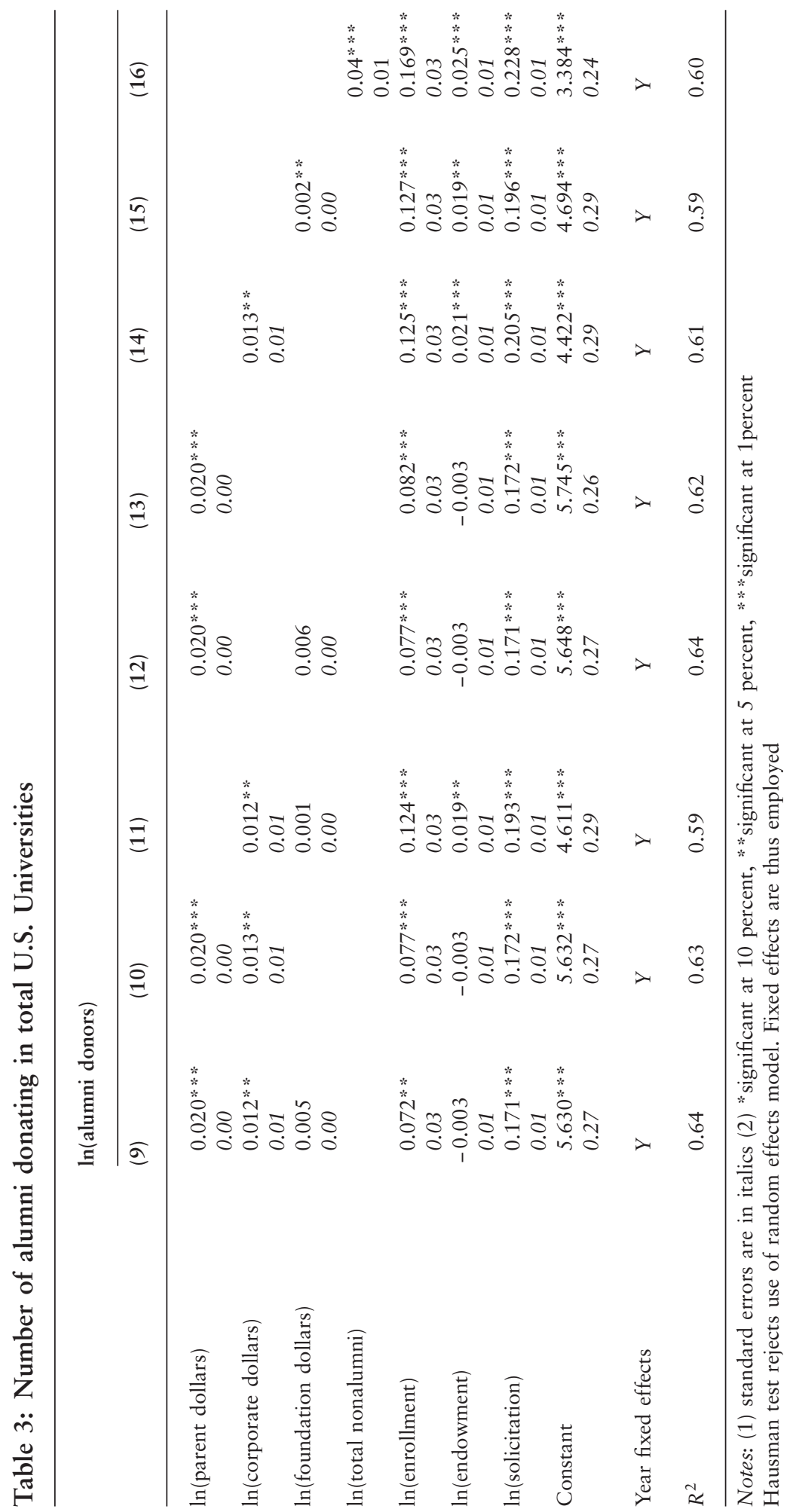


the same, all in natural logarithmic form except for year dummy variables.

Tables 4 and 5 provide results for regressions pertaining to dollar value of alumni in public universities. In general, the magnitude of the results is consistent with the analyses from Table 2, although the sizes and statistical significance of the coefficients have changed and are hence interesting to evaluate. First, looking at Table 4, we can see that for public schools, the coefficients on nonalumni giving support crowd-in for parents, corporations, and for the total sum in model (24) are statistically significant at the 1 percent level and are positive. The coefficient on foundation dollars, however, alternates between positive and negative values, depending on the equation. It is no longer significant, though, and the coefficients are extremely small and close to 0 . Thus, the crowd-in effect on alumni dollars only is only affected by parental and corporate donative behavior in the public school arena.

Examining the public university regressions in Tables 4 and 5 more closely, we see that in Table 4, the crowd-in effect coefficients range from 4.1 to 4.5 percent for parents and 5.3 to 6.9 percent for corporations, and is approximately 6 percent for the aggregate sum of parents, corporations, and foundations. Hence, if in year $(t-1)$ a public university experiences a 1 percent increase in the donation value of parent or corporations, then in year $t$ the university can predict to see a positive percent increase in alumni dollar value, excluding foundation dollar donations. Parent and corporate dollars may provide a strong quality signal to alumni, whereas foundation dollars may not.

For total alumni donors to public universities in Table 5, the statistical story more closely resembles the one in the previous section. The coefficients on parents, corporations, and foundations are all statistically significant and positive. Thus, all nonalumni giving supports a crowd-in hypothesis for number of alumni who donate.

Tables 6 and 7 provide the regression analyses on the cohort of private universities. In Table 6, the coefficients on parent, foundation, and total nonalumni dollars are positive and significant. The values range from 1.9 to 2.1 percent for parents, 1.7 to 3.4 percent for foundations, and 11 percent for total dollars. The coefficients on corporate dollars are positive, although not statistically significant. Hence, aside from corporate dollars, there is significant evidence that a crowd-in effect exists between nonalumni dollars in year $(t-1)$ and alumni dollars in year $t$.

In Table 7, the coefficients on parents are statistically significant and positive. Both corporate and foundation dollars are positive. They, however, do vacillate in their level of statistical significance. Finally, the last equation provides positive evidence that cumulative nonalumni donations to private institutions will have a positive crowd-in effect on their alumni.

From these four tables, it is important to note the following: the coefficients of public universities are greater than the crowd-in effect coefficients in the total sample analyses from the prior section, whereas for 


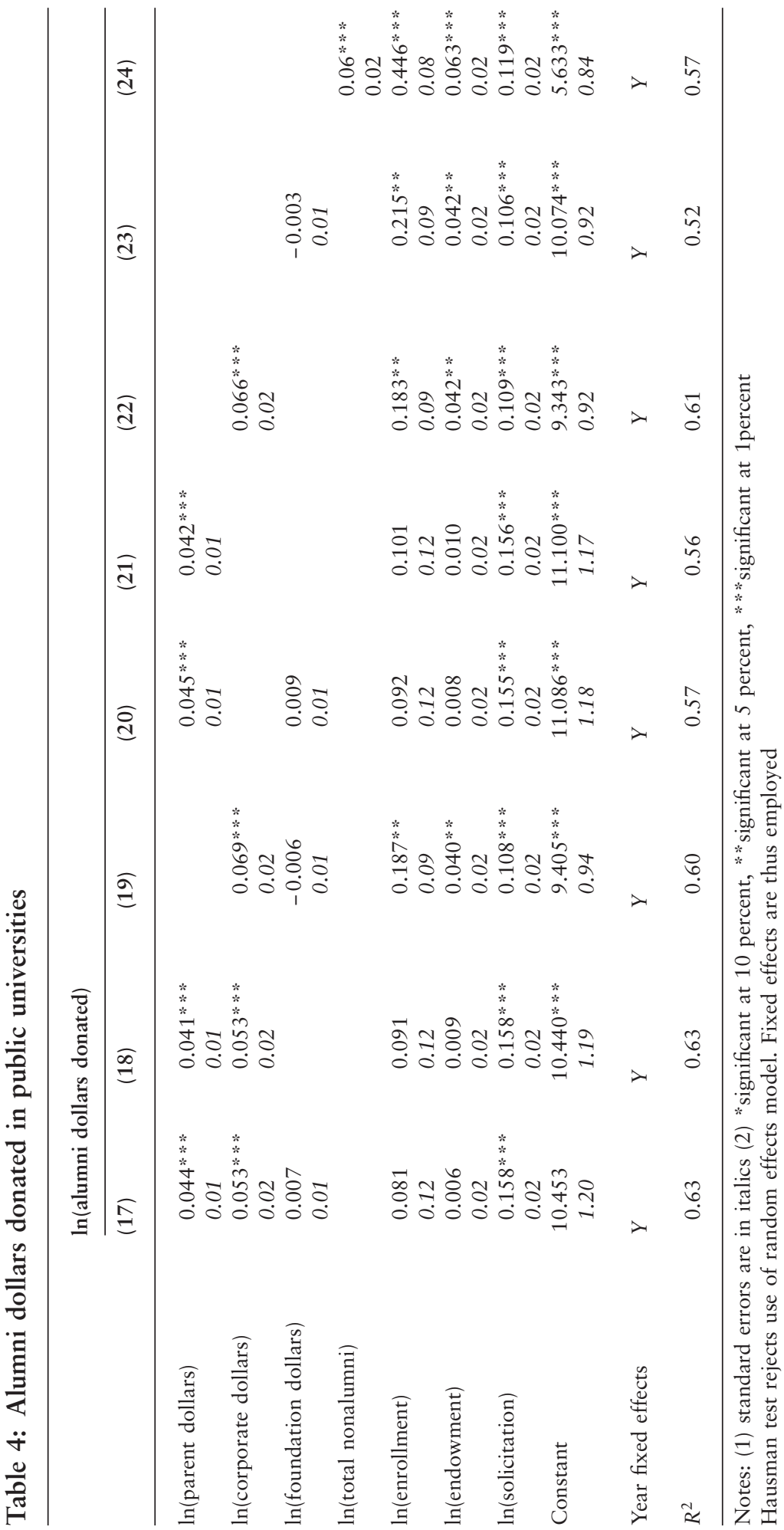




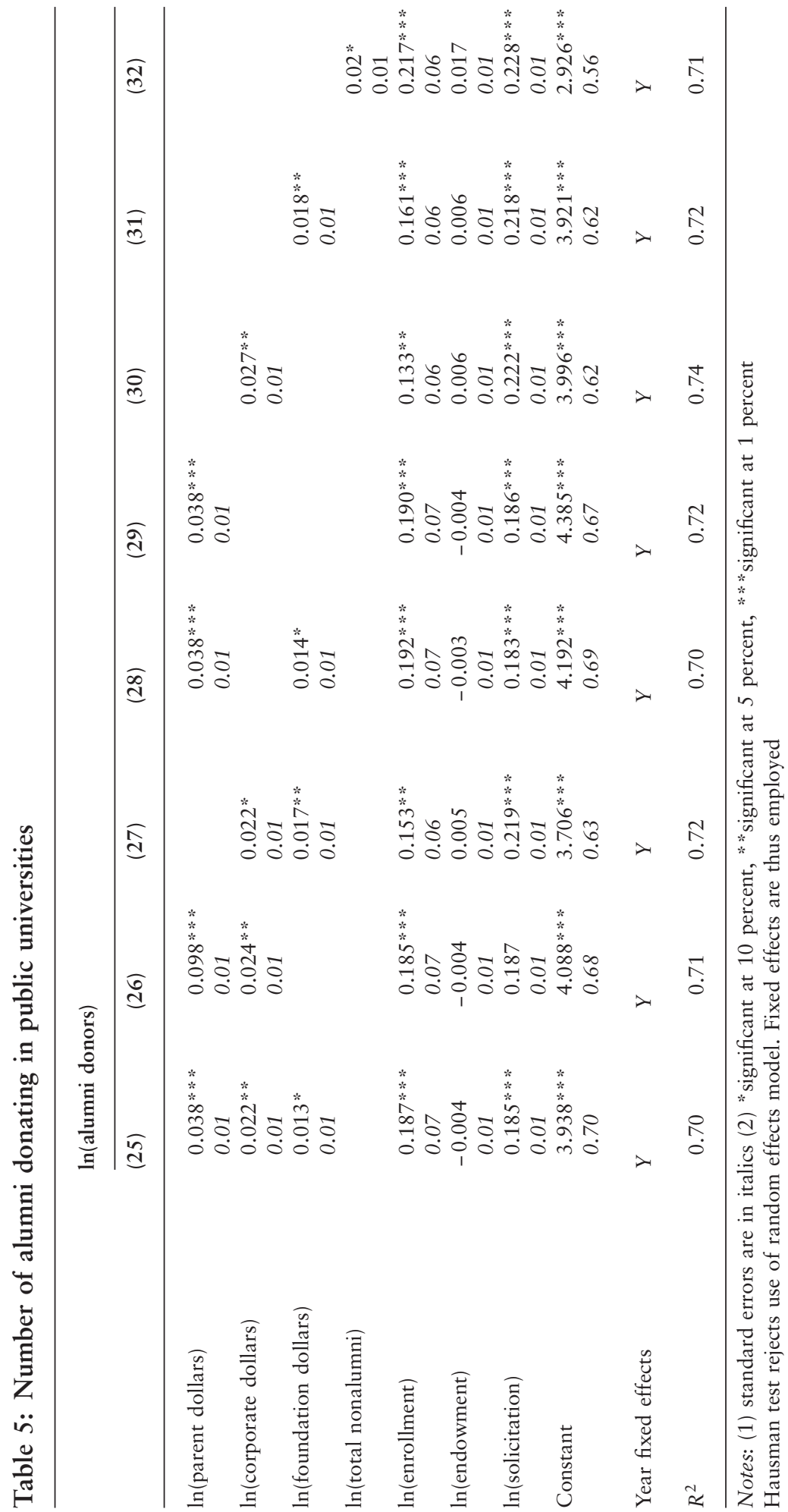




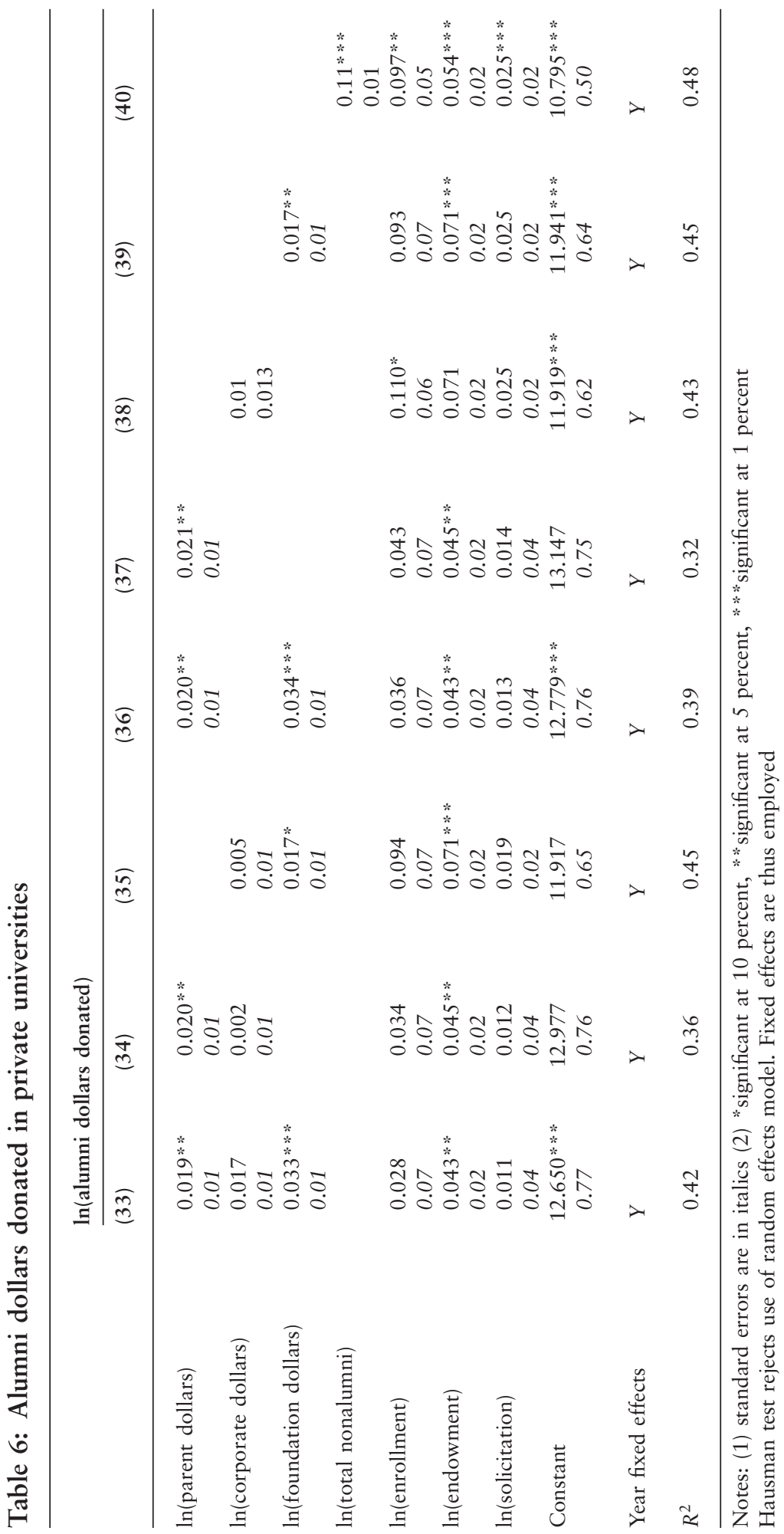




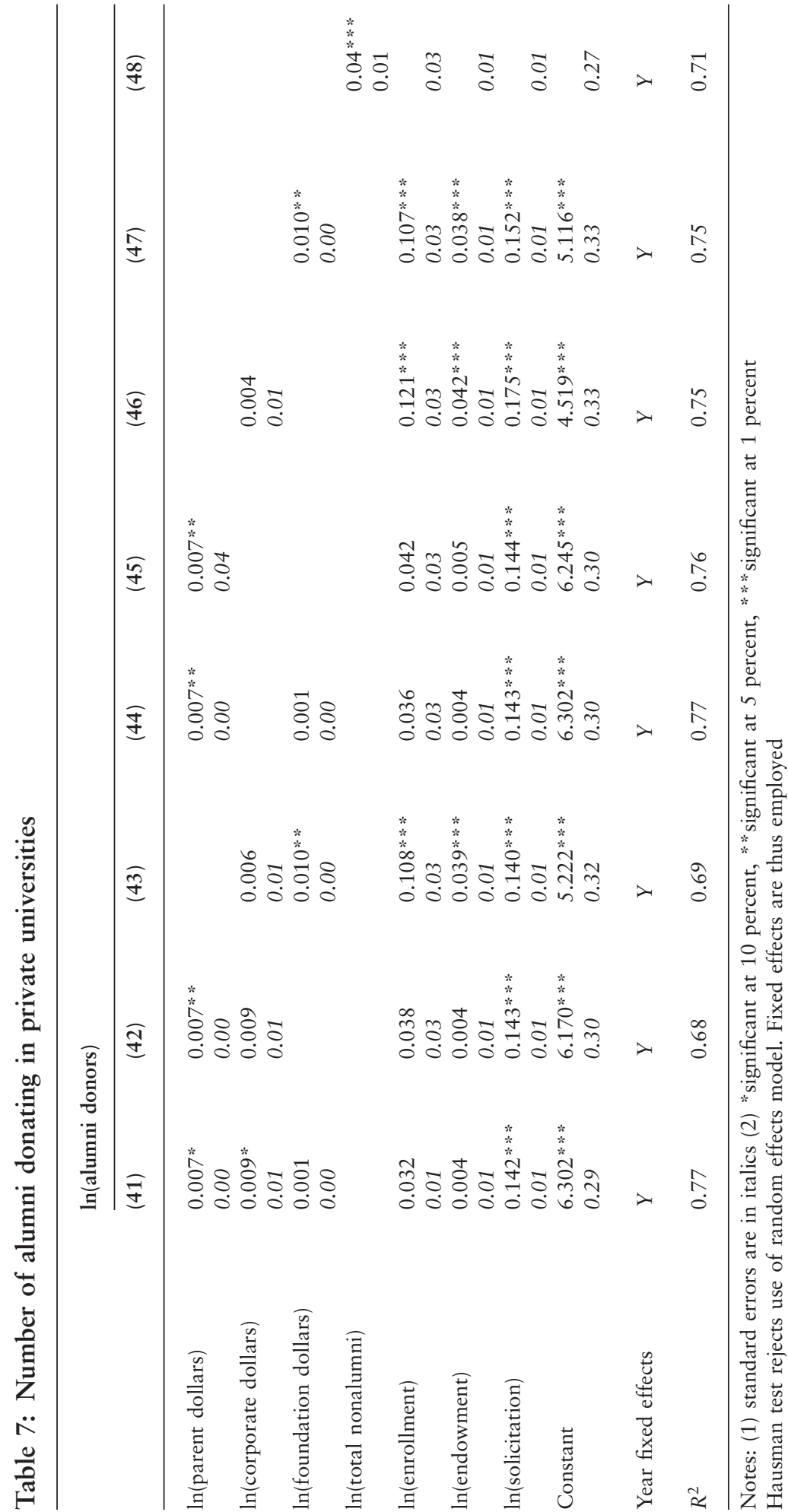


private universities, the crowd-in coefficients are less than those from Tables 2 and 3 and hence less than the public university coefficients. In essence, in a public school, the returns on a percentage increase on a nonalumni contribution are greater than they are for the total school or private schools samples.

The intuition behind this distinction in the crowd-in effect is twofold. First, a nonalumni dollar donated at a public university may exhibit a greater signal of a change in institutional quality than in the larger sample or in the private school sample. Thus, students in public institutions may be more affected by the signal emitted by an additional dollar donated in the previous year from a nonalumni private source. Secondly, students in the public school sample may be less affluent on average than those in the total or private school sample. Alumni in a private school may, on average, be more affluent. Thus, the private school alumni may be less influenced by other sources of donation because these alumni have already been donating in previous years. Additionally, those alumni who would donate a particular amount to their private institutions may do so regardless of other signals in quality, simply because they have the financial resources to do so.

\section{Conclusion}

Each year, millions upon millions of dollars are donated to universities within the United States. These funds come from a variety of sources, which, include alumni, parents, corporations, and foundations. From these major sources of funding,
I have analyzed the effect of one group's behavior on another. In general, the results support a crowd-in effect: a donation given to university $i$ in year $(t-1)$ will affect the donation given by an alumnus in year $t$.

To support these claims, I have analyzed which factors affect changes in alumni donations, using a two-way fixed-effects model of panel data for the period 1995 to 2006. From our analyses in this paper of three samples-total US schools, public schools, and private schools-it is apparent that there is robustness of my economic model employed in this paper. In all full-regression models (and in fact in most models generally), the key coefficients in my regressions are positive and highly statistically significant, demonstrating that nonprivate donations-ceteris paribus - may have a multiplier effect on alumni donations in subsequent years.

The results of this paper have major academic and practical implications. Academically, this paper highlights two important conclusions. First, I provide a link between the utility maximization theory of economic agents (i.e., university alumni) and empirical donative behavior. Second, this paper provides more conclusive evidence on the crowd-out versus crowd-in debate. As mentioned in the introduction, the theoretical and empirical literature had been unconvincing up to this point. By implementing an economic model that supports either crowd-out or crowd-in effect, this paper, however, has allowed the evidence to speak for itselfevidence that supports the crowd-in hypothesis within higher education.

In addition to having academic weight, this paper also provides 
practical appeal, particularly for those in higher education. In fact, the work in this paper appeals to an array of colleges, both public and private. As this paper has devoted its attention to understanding alumni donative behavior, it is important for administrators to know how one source of funding can affect another. The relationship between nonalumni private donations and alumni contributions can have a major affect on the structure of future alumni solicitation. In this paper, the results I have found imply a positive relationship between nonalumni and alumni donations. That is, crowd-in effects of donations do exist-in public schools, in private schools, and in the aggregate. Although the sizes and magnitudes differ depending on the sample size evaluated, the message is consistently clear throughout: donative behavior inspires further donative behavior.

\section{Acknowledgements}

I acknowledge helpful comments from Erica Johnson, Rebecca Maynard, Walter Theseira, and Matt White. Also, helpful comments were made at the Wharton Applied Economics Seminar at the University of Pennsylvania as well as at the Institute of Education Sciences 2007 Research Conference, Washington DC. All errors are my own.

\section{References}

Abrams, B.A. and Schmitz, M.D. (1978), "The 'crowding-out' effect of government transfers on private charitable contributions," Public Choice, 33, 1, pp. 29-39.

Andreoni, J. (1990), "Impure altruism and donations to public goods: A theory of warm glow giving," Economic Journal, 100, pp. 464-477.
Andreoni, J. (1993), "An experimental test of the public goods crowding-out hypothesis," American Economic Review, 83, (5), 1317-1327.

Andreoni, J. and Payne, A.A. (2001), "Government grants to private charities: Do they crowd out giving or fundraising?," Department of Economics Working Paper, University of Wisconsin.

Brooks, A.C. (2003), “Taxes, subsidies, and listeners like you: Public policy and contributions to public radio," Public Administration Review, 63, 5, pp. 554-561.

Connolly, L.S. (1997), “Does external funding of academic research crowd out institutional support?," Journal of Public Economics, 64, pp. $389-406$.

Ehrenberg, R.G., Rees, D.I. and Brewer, D.J. (1993), "Institutional responses to increased external support for graduate students," Review of Economics and Statistics, 75, 3, pp. 671-682.

Gottfried, M. and Johnson, E. (2006), "Solicitation and donation: An econometric evaluation of alumni generosity in higher education," International Journal of Educational Advancement, 6, 4, pp. 268-281.

Hausman, J. (1978), "Specification tests in econometrics," Econometrica, 46, pp. 1251-1272.

Hodsoll, F.S.M. (1984), "Supporting the arts in the eighties: The view from the National Endowment for the Arts," Annals of American Academy of Political and Social Science, 471, pp. 84-88.

Khanna, J., Posnett, J. and Sandler, T. (1995), "Charity donations in the U.K.: New evidence based on panel data," Journal of Public Economics, 56, pp. 257-272.

Kingma, B.R. (1989), “An accurate measure of the crowd-out effect, income effect, and price effect for charitable contributions," Journal of Political Economy, 97, 5, pp. 1197-1207.

Mackay, R. and Whitney, G. (1980), "The comparative statics of quantity constraints and conditional demands: Theory and Applications," Econometrica, 48, 7, pp. 1727-1744.

McPherson, M.S. and Schapiro, M.O. (1991), Keeping College affordable: Government and Educational Opportunity, The Brookings Institution, Washington, DC.

Mulcahy, K.V. (1992), "Government and the arts in the United States," in R.A. Smith and R. Berman (eds.), Public Policy and the Aesthetic Interest, University of Illinois Press, Chicago.

Rabin, M. (1997), "Psychology and economics," Berkeley Department of Economics Working Paper, No. 97-251. University of California, Berkeley.

Reece, W.S. (1979), "Charitable contributions: New evidence on household behavior," American Economic Review, 69, pp. 142-151. 
Roberts, R.D. (1984), “A positive model of private charity and public transfers," Journal of Political Economy, 92, pp. 136-148.

Rose-Ackerman, S. (1981), "Do government grants to charity reduce private donations," in M. White (ed.), Nonprofit Firms in a Three Sector Economy, Urban Institute, Washington, DC, pp. 95-114.

Rose-Ackerman, S. (1986), "Do government grants to charity reduce private donations?," in S. RoseAckerman (ed.) The Economics of Nonprofit Institutions: Students in Structure and Policy, Oxford University Press, New York, pp. 313-329.

Schiff, J. (1985), "Does government spending crowd-out charitable contributions?," National Tax Journal, 38, pp. 535-546.
Steinberg, R. (1985), "Empirical relations between government spending and charitable donations," Journal of Voluntary Action Research, 14, 2, pp. 54-64.

Sugden, R. (1982), "On the economics of philanthropy," Economic Journal, 92, pp. 341-350.

Vesterlund, L. (2003), “The informational value of sequential fundraising," Journal of Public Economics, 87, pp. 627-657.

Wyszomirski, M.J. and Mulcahy, K.V. (1995), "The organization of public support for the arts," in K.V. Mulcahy and M.J. Wyszomirski (eds.) America's Commitment to Culture, Westview Press, Boulder. 